\title{
Poziom wiedzy na temat profilaktyki przeciwzakrzepowej wśród pacjentów z migotaniem przedsionków
}

\author{
The level of knowledge about thromboprophylaxis among \\ Patients with atrial fibrillation
}

\author{
ANNA EMILIA CHWALISZ ${ }^{1}$ \\ GRAŻYNA CHOJNACKA-KOWALEWSKA ${ }^{2,3}$
}

\begin{abstract}
${ }^{1}$ Wojewódzki Szpital Specjalistyczny im. błogosławionego księdza Jerzego Popiełuszki we Włocławku, Odział Kardiologii, Oddział Wewnętrzny I, Oddział Wewnętrzny II

2 Państwowa Uczelnia Zawodowa we Włocławku, Instytut Nauk o Zdrowiu

3 Wojewódzki Szpital Specjalistyczny im. błogosławionego księdza Jerzego Popiełuszki we Włocławku, Oddział Medycyny Paliatywnej
\end{abstract}

DOI: http://dx.doi.org/10.21784/IwP.2020.014

ISSN: $2451-1846$

\section{Streszczenie:}

Wstęp. We współczesnej terapii pacjentów z migotaniem przedsionków, którzy należą do grupy szczególnie narażonej na udar mózgu, profilaktyczne leczenie przeciwkrzepliwe nabiera podstawowego znaczenia. Rozpoczęcie, a następnie właściwe monitorowanie długotrwałej terapii przeciwzakrzepowej, jest dla tej grupy chorych bardzo istotne. Stosowanie doustnych leków przeciwzakrzepowych znacznie zmniejsza ryzyko wystąpienia udaru niedokrwiennego mózgu, a co za tym idzie, zapewnia dłuższe przeżycie oraz uniknięcie trwałego kalectwa wśród chorych z migotaniem przedsionków. 
Cel. Ocena poziomu wiedzy pacjentów z migotaniem przedsionków na temat profilaktyki przeciwzakrzepowej na oddziałach wewnętrznych i kardiologii Wojewódzkiego Szpitala Specjalistycznego we Włocławku.

Materiał i metody. Grupę badaną stanowiło 100 osób (63 mężczyzn i 37 kobiet) z rozpoznanym migotaniem przedsionków, przyjmujących doustne leki przeciwzakrzepowe. Narzędziem badawczym był autorski kwestionariusz ankiety. W celu oceny ryzyka udaru niedokrwiennego mózgu w tej grupie chorych, zastosowano skalę CHA2DS2-VASc, a pytania dotyczące tych czynników umieszczono $\mathrm{w}$ ankiecie.

Wyniki. Z przeprowadzonych badan wynika, że u każdego pacjenta z rozpoznanym migotaniem przedsionków stosowana jest profilaktyka przeciwzakrzepowa w postaci doustnych antykoagulantów. Większość chorych stosuje leki nowej generacji (NOAC), niewymagające ustalania dawki na podstawie znormalizowanego wskaźnika INR. U 51\% badanych stwierdzono utrwalone migotanie przedsionków. Najliczniejszą grupę stanowili pacjenci w przedziale wiekowym 65-74 lat. Roczne ryzyko wystąpienia udaru mózgu u badanych wynosiło średnio 11\%. W większości pacjenci prawidłowo odpowiadali na pytania dotyczące zasad postępowania podczas stosowania doustnych leków przeciwzakrzepowych, czynników nasilających i osłabiających działanie tych leków oraz objawów ich przedawkowania. Nie zaobserwowano istotnych różnic $\mathrm{w}$ poziomie wiedzy między badanymi kobietami a mężczyznami, natomiast większą wiedzą wykazali się pacjenci młodsi, lepiej wykształceni i deklarujący bardzo dobrą lub zadowalającą sytuację materialną.

Wnioski. Badanie wykazało, że poziom wiedzy pacjentów, na temat profilaktyki przeciwzakrzepowej w migotaniu przedsionków, jest na dobrym poziomie i odpowiada aktualnej wiedzy medycznej.

Słowa kluczowe: migotanie przedsionków, profilaktyka przeciwzakrzepowa, terapia, doustne antykoagulanty, poziom wiedzy, ryzyko udaru mózgu.

\section{Summary:}

Introduction. In modern therapy of patients with atrial fibrillation, which belongs to the group particularly at risk of stroke, prophylactic anticoagulation is of primary importance. The initiation and subsequent proper monitoring of 
long-term anticoagulation therapy is very important for this group of patients. The use of oral anticoagulants significantly reduces the risk of ischemic stroke, and thus ensures longer survival and avoidance of permanent disability among patients with atrial fibrillation.

Aim. Assessment of the level of knowledge of patients with atrial fibrillation on thromboprophylaxis in internal departments and cardiology of the Provincial Specialist Hospital in Włocławek.

Materials and methods. The study group consisted of 100 people (63 men and 37 women) with diagnosed atrial fibrillation, taking oral anticoagulants. The research tool was the author's questionnaire. To assess the risk of ischemic stroke in this group of patients, the CHA2DS2-VASc scale was used and questions about these factors were included in the survey.

Results. Studies show that anticoagulant prophylaxis in the form of oral anticoagulants is used in every patient with diagnosed atrial fibrillation. Most patients use new generation drugs (NOAC) that do not require dose adjustment based on a normalized INR. Persistent atrial fibrillation was found in 51\% of the patients. The most numerous group were patients in the 65-74 age range. The annual risk of stroke in my subjects was on average $11 \%$. In most cases, patients correctly answered questions about the rules of conduct when using oral anticoagulants, factors that increase and weaken the effects of these drugs and the symptoms of their overdose. There were no significant differences in the level of knowledge between the women and men studied, while younger, better educated patients who declared a very good or satisfactory material situation showed more knowledge. Conclusions. The study showed that the level of patients' knowledge about antithrombotic prophylaxis in atrial fibrillation is at a good level and corresponds to current medical knowledge.

Keywords: atrial fibrillation, anticoagulant prophylaxis, therapy, oral anticoagulants, level of knowledge, risk of stroke.

\section{Wstęp}

Migotanie przedsionków jest najczęstszym rodzajem arytmii, będącym przyczyną hospitalizacji. Mimo postępów diagnostycznych 
i terapeutycznych obserwuje się ciągły wzrost zachorowalności na tę jednostkę chorobową. Dotyczy to zarówno starszych, jak i coraz młodszych osób. U znacznej części pacjentów migotanie przedsionków przebiega w sposób bezobjawowy i niejednokrotnie prawidłowa diagnoza zostaje postawiona podczas przypadkowego wykonywania badania EKG. Występowanie arytmii może się przyczyniać do powstania wielu powikłań zakrzepowo-zatorowych, z których za najbardziej zagrażające życiu chorego uznaje się wystąpienie udaru mózgu. Dlatego też zapobieganie powikłaniom zakrzepowo-zatorowym jest głównym celem terapeutycznym u chorych z migotaniem przedsionków. Doustne leczenie przeciwkrzepliwe to podstawa profilaktyki incydentów zakrzepowo-zatorowych u tych chorych. Regularne przyjmowanie leków, kontrola poziomu wskaźników krzepnięcia krwi, a przede wszystkim zrozumienie istoty terapii i postępowanie zgodnie $\mathrm{z}$ zaleceniami, $\mathrm{w}$ istotny sposób przyczyniają się do profilaktyki powikłań u chorych z tą arytmią. Stosowanie doustnych leków przeciwkrzepliwych w sposób przewlekły, z jednoczesnym zachowaniem kontroli poziomu wskaźnika INR, obniża ryzyko wystąpienia udaru mózgu o 2/3 [1]. Zapewnia to uniknięcie trwałego kalectwa i znacznie dłuższe życie wśród pacjentów z migotaniem przedsionków. Profilaktyka przeciwzakrzepowa wymaga trwałej współpracy pacjentów z pracownikami służby zdrowia. Skuteczność profilaktyki wymaga wiedzy na temat jej założeń i zasad, a bezpieczeństwo zależy od uzmysłowienia sobie możliwych działań niepożądanych. Tymczasem w licznych publikacjach zwraca się uwage na duże braki w edukacji pacjentów z migotaniem przedsionków stosujących doustne antykoagulanty [2].

\section{Cel}

Celem badań jest określenie poziomu wiedzy pacjentów z migotaniem przedsionków, na temat profilaktyki zakrzepowo-zatorowej, $\mathrm{z}$ oceną znajomości zasad przyjmowania leku przeciwkrzepliwego. 


\section{Materiał i metody}

W badaniach grupy pacjentów z oddziałów wewnętrznych i kardiologii Wojewódzkiego Szpitala Specjalistycznego we Włocławku posłużono się metodą sondażu diagnostycznego. Jako technikę wybrano ankietowanie, a narzędziem badawczym, wykorzystanym w pracy, był autorski kwestionariusz ankiety, z zawartą w niej skalą do oceny ryzyka powikłań zakrzepowo-zatorowych $\mathrm{u}$ chorych $\mathrm{z}$ migotaniem przedsionków.

Badania zostały przeprowadzone na początku 2020 roku. Na ich przeprowadzenie otrzymano zgodę Komisji Bioetycznej. Badaniem zostało objętych 100 dorosłych pacjentów dwóch oddziałów internistycznych i oddziału kardiologii - 37 kobiet i 63 mężczyzn. Najwięcej respondentów znajdowało się w grupie wiekowej 65-74 lat (41\%), a najmniej w grupach 18-44 lata i 45-54 lata (po 8\%). Najwięcej kobiet było w przedziale 55-64 lat (18\%), a w najmłodszej grupie kobiet nie było w ogóle. Najwięcej mężczyzn zaś miało 65-74 lata (31\%).

W badaniach statystycznych przeprowadzono test zgodności z rozkładem normalnym, obliczono testy Kruskala-Wallisa, $U$ Manna Whitneya oraz obliczono szereg analiz Chi - kwadrat dla jednej zmiennej. Za poziom istotności w niniejszym rozdziale przyjęto klasyczne $\alpha \leq 0,05$.

\section{Wyniki}

Zbiorczo wyniki wszystkich wyliczonych statystyk opisowych wraz z rezultatami testów normalności rozkładu przedstawiono w tabeli 1 . 
Tab. 1. Podstawowe statystyki opisowe mierzonych zmiennych ilościowych wraz z testem Kołmogorowa-Smirnowa.

\begin{tabular}{lccccccccc}
\hline & $M$ & $M e$ & $S D$ & $S k$. & Kurt. & Mini. & Maks. & K-S & $p$ \\
\hline Poziom wiedzy & 8,84 & 10,00 & 2,92 & $-0,65$ & $-0,83$ & 2,00 & 12,00 & 0,19 & $<0,001$ \\
Skala CHA2DS2-VASc & 4,20 & 4,00 & 1,68 & $-0,78$ & 0,95 & 0,00 & 8,00 & 0,17 & $<0,001$ \\
\hline
\end{tabular}

$M$ - średnia; $M e$ - mediana; $S D$ - odchylenie standardowe; $S k$. skośność; Kurt. - kurtoza; $K-S$ - wynik testu Kołmogorowa-Smirnowa; $p$ - istotność testu KołmogorowaSmirnowa

Następnie zaprezentowano wyniki częstości punktów w skali CHA2DS2-VASc - tabela 2.

Tab. 2. Tabela częstości: skala CHA2DS2-VASc.

\begin{tabular}{llcc}
\hline & & Częstość & Procent \\
\hline & $0 \mathrm{pkt}$ & 7 & 7,0 \\
& $1 \mathrm{pkt}$ & 1 & 1,0 \\
& $2 \mathrm{pkt}$ & 2 & 2,0 \\
Skala CHA2DS2-VASc & $3 \mathrm{pkt}$ & 18 & 18,0 \\
& $4 \mathrm{pkt}$ & 23 & 23,0 \\
& $5 \mathrm{pkt}$ & 32 & 32,0 \\
& $6 \mathrm{pkt}$ & 11 & 11,0 \\
& $7 \mathrm{pkt}$ & 5 & 5,0 \\
& $8 \mathrm{pkt}$ & 1 & 1,0 \\
& 0gółem & 100 & 100,0 \\
\hline
\end{tabular}

Tab 3. Tabela częstości: Jaki typ migotania przedsionków rozpoznano u Pana(i)?

\begin{tabular}{|llccrr|}
\hline & & K & M & Częstość & Procent \\
\hline Jaki typ migotania & Napadowe & 4 & 13 & 17 & 17,0 \\
przedsionków & Przetrwałe & 5 & 1 & 6 & 6,0 \\
rozpoznano & Utrwalone & 21 & 30 & 51 & 51,0 \\
u Pana(i)? & Nie wiem & 7 & 19 & 26 & 26,0 \\
Ogółem & & 37 & 63 & 100 & 100,0 \\
\hline
\end{tabular}

$\chi^{2}=8,3634 ; d f=3 ; p<0,05$ 
Okazało się, że u większości osób rozpoznano utrwalone migotanie przedsionków (51\%). Większość osób leczy się z powodu zastoinowej niewydolności serca (92\%). Większość osób badanych ma rozpoznane nadciśnienie tętnicze i jest ono leczone (81\%). Mniej niż polowa (42\%) badanych choruje na cukrzycę. Okazało się, że większość osób badanych nie przebyło udaru mózgu, przemijającego niedokrwienia mózgu lub innych powikłań zakrzepowo - zatorowych (78\%). Większość osób badanych przebyło zawał mięśnia sercowego lub miażdżycową chorobę tętnic obwodowych (71\%).

Większość osób badanych twierdzi, że migotanie przedsionków może prowadzić do groźnych dla życia powikłań (65\%).

Tab. 4. Tabela częstości: Jaki lek przeciwzakrzepowy Pan(i) przyjmuje?

\begin{tabular}{|c|c|c|c|c|c|}
\hline & & $\mathrm{K}$ & M & Częstość & Procent \\
\hline \multirow{7}{*}{$\begin{array}{l}\text { Jaki lek } \\
\text { przeciwzakrzepowy } \\
\text { Pan(i) przyjmuje? }\end{array}$} & Sintrom & 1 & 3 & 4 & 4,0 \\
\hline & Warfin & 3 & 14 & 17 & 17,0 \\
\hline & & 16 & 21 & & \\
\hline & $\begin{array}{l}\text { Xarelto } \\
\text { Pradaxa }\end{array}$ & $\begin{array}{r}16 \\
8\end{array}$ & $\begin{array}{r}21 \\
9\end{array}$ & $\begin{array}{l}37 \\
17\end{array}$ & $\begin{array}{l}37,0 \\
170\end{array}$ \\
\hline & Eliquis & 9 & 16 & 25 & 25,0 \\
\hline & Inny & 0 & 0 & 0 & 0,0 \\
\hline & Ogółem & 37 & 63 & 100 & 100,0 \\
\hline
\end{tabular}

$\chi^{2}=4,3459 ; d f=4 ; p<0,05$

Możemy za to zaobserwować dużą różnicę w stosowaniu „starych” i „nowych” leków przeciwzakrzepowych, gdzie tę drugą grupę stosuje $79 \%$ badanych. 
Tab. 5. Tabela częstości: Jak często należy kontrolować wskaźnik INR podczas przyjmowania leków przeciwzakrzepowych typu Warfin i Acenocumarol?

\begin{tabular}{llcc}
\hline & & Częstość & $\begin{array}{c}\text { Pro- } \\
\text { cent }\end{array}$ \\
\hline & Raz w tygodniu & 5 & 5,0 \\
Jak często należy kontrolować wskaź- & Raz w miesiącu & 61 & 61,0 \\
nik INR podczas przyjmowania leków & Raz na pół roku & 12 & 12,0 \\
przeciwzakrzepowych typu Warfin i & Raz na rok & 11 & 11,0 \\
Acenocumarol? & Nie trzeba & 11 & 11,0 \\
& Ogółem & 100 & 100,0 \\
\hline
\end{tabular}

$\chi^{2}=106,60 ; d f=4 ; p<0,001$

Stwierdzono istotny rezultat testu Chi-kwadrat, co oznacza, że zaobserwowane liczebności różnią się istotnie od liczebności oczekiwanych. Okazało się, że większość osób badanych twierdzi, że należy raz w miesiącu kontrolować wskaźnik INR podczas przyjmowania leków przeciwzakrzepowych typu Warfin i Acenocumarol (61\%).

Tab. 6. Tabela częstości: Kto ustala Panu(i) dawkę leku na podstawie wyniku INR?

\begin{tabular}{|c|c|c|c|}
\hline & & $\begin{array}{l}\text { Czę- } \\
\text { stość }\end{array}$ & Procent \\
\hline \multirow{5}{*}{$\begin{array}{l}\text { Kto ustala Panu(i) dawkę } \\
\text { leku na podstawie wyniku } \\
\text { INR? }\end{array}$} & Lekarz rodzinny & 15 & 15,0 \\
\hline & Inny lekarz & 4 & 4,0 \\
\hline & Ja samodzielnie & 2 & 2,0 \\
\hline & $\begin{array}{l}\text { Przyjmuję lek niewymagający } \\
\text { ustalania dawki }\end{array}$ & 79 & 79,0 \\
\hline & Ogółem & 100 & 100,0 \\
\hline
\end{tabular}

$\chi^{2}=159,44 ; d f=3 ; p<0,001$

Analiza wykazała istotny rezultat testu Chi-kwadrat, co oznacza, że zaobserwowane liczebności różnią się istotnie od liczebności 
oczekiwanych. Okazało się, że większość osób badanych przyjmuje leki niewymagające ustalania dawki (79\%).

Tab. 7. Tabela częstości: Jaka jest wartość terapeutyczna wskaźnika INR?

\begin{tabular}{llcc}
\hline & & Częstość & Procent \\
\hline & $0,8-1,2$ & 20 & 20,0 \\
Jaka jest wartość terapeutyczna wskaźnika INR? & $2-3$ & 74 & 74,0 \\
& powyżej 5 & 6 & 6,0 \\
& Ogółem & 100 & 100,0 \\
\hline
\end{tabular}

$\chi^{2}=77,36 ; d f=2 ; p<0,001$

Odnotowano istotny rezultat testu Chi-kwadrat, co oznacza, że zaobserwowane liczebności różnią się istotnie od liczebności oczekiwanych. Okazało się, że większość osób badanych twierdzi, że wartość terapeutyczna wskaźnika INR jest pomiędzy 2 a 3 (74\%).

Tab. 8. Tabela częstości: Z jakiego powodu przyjmuje Pan(i) lek przeciwzakrzepowy?

\begin{tabular}{llcc}
\hline & & $\begin{array}{c}\text { Czę- } \\
\text { stość }\end{array}$ & Procent \\
\hline & $\begin{array}{l}\text { Chroni przed powikłaniami zakrze- } \\
\text { powo-zatorowymi, głównie przed uda- }\end{array}$ & 75 & 75,0 \\
& $\begin{array}{l}\text { rem mózgu } \\
\text { Chroni przed kolejnymi napadami migo- }\end{array}$ & 7 & 7,0 \\
$\begin{array}{l}\text { Z jakiego powodu } \\
\text { przyjmuje Pan(i) lek } \\
\text { przeciwzakrzepowy? }\end{array}$ & $\begin{array}{l}\text { Mania przedsionków } \\
\text { niom zapobiegać nadmiernym krwawie- }\end{array}$ & 4 & 4,0 \\
& Nie wiem, tak zlecił lekarz & 14 & 14,0 \\
& Ogółem & 100 & 100,0 \\
\hline
\end{tabular}

$\chi^{2}=135,44 ; d f=3 ; p<0,001$ 
Stwierdzono istotny rezultat testu Chi-kwadrat, co oznacza, że zaobserwowane liczebności różnią się istotnie od liczebności oczekiwanych. Okazało się, że większość osób badanych przyjmuje leki przeciwzakrzepowe z powodu ochrony przed powikłaniami zakrzepowo-zatorowymi, głównie przed udarem mózgu (75\%).

Tab. 9. Tabela częstości: Czy leki przeciwkrzepliwe mogą być niebezpieczne dla osoby je przyjmującej?

\begin{tabular}{llcc}
\hline & & Częstość & $\begin{array}{r}\text { Pro- } \\
\text { cent }\end{array}$ \\
\hline & $\begin{array}{l}\text { Tak, zbyt duża dawka } \\
\text { może wywołać krwawie- }\end{array}$ & 84 & 84,0 \\
nie & & \\
$\begin{array}{l}\text { Czy leki przeciwkrzepliwe } \\
\text { mogą być niebezpieczne dla } \\
\text { osoby je przyjmującej? }\end{array}$ & $\begin{array}{l}\text { Nie, są całkowicie bez- } \\
\text { pieczne }\end{array}$ & 3 & 3,0 \\
& Nie wiem & 13 & 13,0 \\
& Ogółem & 100 & 100,0 \\
\hline
\end{tabular}

$\chi^{2}=117,02 ; d f=2 ; p<0,001$

Analiza wykazała istotny rezultat testu Chi-kwadrat, co oznacza, że zaobserwowane liczebności różnią się istotnie od liczebności oczekiwa-nych. Okazało się, że większość osób badanych twierdzo, że leki przeciwkrzepliwe mogą być niebezpieczne dla osoby je przyjmującej (84\%). 
Tab. 10. Tabela częstości: Czy przyjmowanie leków przeciwbólowych, przeciwzapalnych, takich jak: Paracetamol, Aspiryna, Ketonal, Pyralgina, w trakcie stosowanej terapii przeciwkrzepliwej jest bezpieczne?

\begin{tabular}{|c|c|c|c|}
\hline & & Częstość & Procent \\
\hline \multirow{4}{*}{$\begin{array}{l}\text { Czy przyjmowanie leków prze- } \\
\text { ciwbólowych, przeciwzapal- } \\
\text { nych, takich jak: Paracetamol, } \\
\text { Aspiryna, Ketonal, Pyralgina, w } \\
\text { trakcie stosowanej terapii } \\
\text { przeciwkrzepliwej jest bez- } \\
\text { pieczne? }\end{array}$} & $\begin{array}{l}\text { Tak, nie ma przeciwwskazań } \\
\text { do ich stosowania }\end{array}$ & 17 & 17,0 \\
\hline & $\begin{array}{l}\text { Nie, ponieważ nasilają dzia- } \\
\text { łanie leków przeciwkrzepli- } \\
\text { wych i mogą powodować } \\
\text { krwawienia }\end{array}$ & 65 & 65,0 \\
\hline & Nie wiem & 18 & 18,0 \\
\hline & Ogółem & 100 & 100,0 \\
\hline
\end{tabular}

$\chi^{2}=45,14 ; d f=2 ; p<0,001$

Odnotowano istotny rezultat testu Chi-kwadrat, co oznacza, że zaobserwowane liczebności różnią się istotnie od liczebności oczekiwanych. Okazało się, że większość osób badanych twierdzi, że przyjmowanie leków przeciwbólowych, przeciwzapalnych, takich jak: Paracetamol, Aspiryna, Ketonal, Pyralgina, w trakcie stosowanej terapii przeciwkrzepliwej nie jest bezpieczne, ponieważ nasila działanie leków (65\%).

Tab. 11. Tabela częstości: Czy w trakcie stosowania leku przeciwkrzepliwego można otrzymywać zastrzyki domięśniowe?

\begin{tabular}{llcc}
\hline & & Częstość & Procent \\
\hline & Nie, nie wolno & 17 & 17,0 \\
& W miarę możliwości należy uni- & & \\
$\begin{array}{l}\text { Czy w trakcie stosowania } \\
\text { leku przeciwkrzepliwego } \\
\text { można otrzymywać zastrzyki a w razie ich konieczności }\end{array}$ & zastosować kilkuminutowy & 65 & 65,0 \\
domięśniowe? & ucisk & & \\
& Można & 18 & 18,0 \\
& Ogółem & 100 & 100,0 \\
\hline
\end{tabular}

$\chi^{2}=45,14 ; d f=2 ; p<0,001$ 
Stwierdzono istotny rezultat testu Chi-kwadrat, co oznacza, że zaobserwowane liczebności różnią się istotnie od liczebności oczekiwanych. Okazało się, że większość osób badanych twierdzi, że w trakcie stosowania leku przeciwkrzepliwego w miarę możliwości należy unikać zastrzyków domięśniowych, a w razie ich konieczności zastosować kilkuminutowy ucisk (65\%).

Tab. 12. Tabela częstości: Spożywanie zielonych warzyw, takich jak: brokuły, sałata, szpinak, kapusta, zwiększa czy zmniejsza wartość INR?

\begin{tabular}{|c|c|c|c|}
\hline & & $\begin{array}{l}\text { Czę- } \\
\text { stość }\end{array}$ & $\begin{array}{l}\text { Pro- } \\
\text { cent }\end{array}$ \\
\hline \multirow{4}{*}{$\begin{array}{l}\text { Spożywanie zielonych warzyw, } \\
\text { takich jak: brokuły, sałata, szpi- } \\
\text { nak, kapusta, zwiększa czy } \\
\text { zmniejsza wartość INR? }\end{array}$} & $\begin{array}{l}\text { Zmniejsza INR, ponieważ osła- } \\
\text { biają one działanie antykoagu- } \\
\text { lantów }\end{array}$ & 84 & 84,0 \\
\hline & $\begin{array}{l}\text { Zwiększa INR, ponieważ nasi- } \\
\text { lają działanie antykoagulantów }\end{array}$ & 5 & 5,0 \\
\hline & Nie wiem & 11 & 11,0 \\
\hline & Ogółem & 100 & 100,0 \\
\hline
\end{tabular}

$\chi^{2}=116,06 ; d f=2 ; p<0,001$

Analiza wykazała istotny rezultat testu Chi-kwadrat, co oznacza, że zaobserwowane liczebności różnią się istotnie od liczebności oczekiwanych. Okazało się, że większość osób badanych twierdzi, że spożywanie zielonych warzyw, takich jak: brokuły, sałata, szpinak, kapusta zmniejsza wartość INR, ponieważ osłabiają one działanie antykoagulantów (84\%). 
Tab. 13. Tabela częstości: Czy alkohol nasila działanie leków „rozrzedzających krew"?

\begin{tabular}{llcc}
\hline & & Częstość & Procent \\
\hline & Tak nasila i może spowo- & 82 & 82,0 \\
Czy alkohol nasila działanie le- & dować krwawienia & 9 & 9,0 \\
ków „rozrzedzających krew”? & Nie, nie ma wpływu & 9 & 9,0 \\
& Ogółem & 100 & 100,0 \\
\hline
\end{tabular}

$\chi^{2}=106,58 ; d f=2 ; p<0,001$

Odnotowano istotny rezultat testu Chi-kwadrat, co oznacza, że zaobserwowane liczebności różnią się istotnie od liczebności oczekiwanych. Okazało się, że większość osób badanych twierdzi, że alkohol nasila działanie leków „rozrzedzających krew” (82\%).

Tab. 14. Tabela częstości: O czym mogą świadczyć objawy, takie jak: krwawienia z nosa lub dziąseł, czarne stolce, siniaki, ciemniejszy mocz?

\begin{tabular}{llcc}
\hline & & Częstość & Procent \\
\hline & $\begin{array}{l}\text { Są to pierwsze objawy } \\
\text { przedawkowania leku }\end{array}$ & 83 & 83,0 \\
$\begin{array}{l}\text { O czym mogą świadczyć objawy, } \\
\text { takie jak: krwawienia z nosa lub }\end{array}$ & przeciwzakrzepowego & & \\
$\begin{array}{l}\text { dziąseł, czarne stolce, siniaki, } \\
\text { ciemniejszy mocz? }\end{array}$ & O złej diecie & 4 & 4,0 \\
& Nie wiem & 13 & 13,0 \\
& Ogółem & 100 & 100,0 \\
\hline
\end{tabular}

$\chi^{2}=112,22 ; d f=2 ; p<0,001$

Stwierdzono istotny rezultat testu Chi-kwadrat, co oznacza, że zaobserwowane liczebności różnią się istotnie od liczebności oczekiwanych. Okazało się, że większość osób badanych twierdzi, że objawy takie jak: krwawienia z nosa lub dziąseł, czarne stolce, siniaki, ciemniejszy mocz świadczą o pierwszych objawach przedawkowania leku przeciwzakrzepowego (83\%). 
Tab. 15. Tabela częstości: Czy przed planowanym zabiegiem chirurgicznym, okulistycznym lub stomatologicznym należy poinformować lekarza o przyjmowaniu leków przeciwzakrzepowych?

\begin{tabular}{llcc}
\hline & & Częstość & Procent \\
\hline Czy przed planowanym zabiegiem chirur- & Nie, nie trzeba & 17 & 17,0 \\
gicznym, okulistycznym lub stomatologicz- & Tak, koniecznie & 64 & 64,0 \\
nym należy poinformować lekarza o przyj- & Nie wiem & 19 & 19,0 \\
mowaniu leków przeciwzakrzepowych? & Ogółem & 100 & 100,0 \\
\hline
\end{tabular}

$\chi^{2}=42,38 ; d f=2 ; p<0,001$

Analiza wykazała istotny rezultat testu Chi-kwadrat, co oznacza, że zaobserwowane liczebności różnią się istotnie od liczebności oczekiwanych. Okazało się, że większość osób badanych twierdzi, że koniecznie przed planowanym zabiegiem chirurgicznym, okulistycznym lub stomatologicznym należy poinformować lekarza o przyjmowaniu leków przeciwzakrzepowych (64\%).

Tab. 16. Tabela częstości: Co by Pan(i) zrobił(a), gdyby zapomniał(a) przyjąć antykoagulant $\mathrm{w}$ danym dniu lub o ustalonej godzinie?

\begin{tabular}{llcc}
\hline & & Częstość Procent \\
\hline & $\begin{array}{l}\text { Wezmę zapomnianą dawkę w } \\
\text { jak najkrótszym czasie od wy- }\end{array}$ & & \\
& $\begin{array}{l}\text { znaczonego, a w następnych } \\
\text { dniach wg wcześniej ustalonego } \\
\text { schematu }\end{array}$ & 82 & 82,0 \\
$\begin{array}{l}\text { Co by Pan(i) zrobił(a), gdyby } \\
\text { zapomniał(a) przyjąć antyko- } \\
\text { agulant w danym dniu lub o } \\
\text { ustalonej godzinie? }\end{array}$ & $\begin{array}{l}\text { Pominę dawkę całkowicie, a ko- } \\
\text { lejną przyjmę o stałej porze w } \\
\text { dniu następnym } \\
\text { Zwiększę ilość leku następnego } \\
\text { dnia o pominiętą dawkę } \\
\text { Ogółem }\end{array}$ & 5 & \multirow{2}{*}{5,0} \\
& & 13 & 13,0 \\
\hline$\chi^{2}=107,54 ; d f=2 ; p<0,001$ & & & 100,0 \\
\hline
\end{tabular}


Odnotowano istotny rezultat testu Chi-kwadrat, co oznacza, że zaobserwowane liczebności różnią się istotnie od liczebności oczekiwanych. Okazało się, że większość osób badanych w przypadku nie przyjęcia antykoagulant $\mathrm{w}$ danym dniu lub o ustalonej godzinie weźmie zapomnianą dawkę w jak najkrótszym czasie od wyznaczonego, a w następnych dniach wg wcześniej ustalonego schematu (82\%).

Tab. 17. Tabela częstości: Czy ściśle przestrzega Pan(i) dawkowania i pory przyjmowania leku przeciwkrzepliwego?

\begin{tabular}{llcc}
\hline & & Częstość & Procent \\
\hline $\begin{array}{l}\text { Czy ściśle przestrzega } \\
\begin{array}{l}\text { Pan(i) dawkowania i pory } \\
\text { przyjmowania leku prze- }\end{array}\end{array}$ & $\begin{array}{l}\text { Przyjmuję codziennie, ale o } \\
\text { różnych porach dnia }\end{array}$ & 9 & 80,0 \\
ciwkrzepliwego? & $\begin{array}{l}\text { Zdarza mi się zapomnieć } \\
\text { Ogółem }\end{array}$ & 11 & 9,0 \\
\hline
\end{tabular}

$\chi^{2}=98,06 ; d f=2 ; p<0,001$

Stwierdzono istotny rezultat testu Chi-kwadrat, co oznacza, że zaobserwowane liczebności różnią się istotnie od liczebności oczekiwanych. Okazało się, że większość osób badanych ściśle przestrzega dawkowania i pory przyjmowania leku przeciwkrzepliwego (80\%).

Tab. 18. Tabela częstości: Czy czuje Pan(i), że ma wystarczającą wiedzę o swojej chorobie i jej leczeniu?

\begin{tabular}{llcc}
\hline & & \multicolumn{1}{c}{ Częstość } & $\begin{array}{c}\text { Pro- } \\
\text { cent }\end{array}$ \\
\hline & Tak, wiem wystarczająco dużo & 27 & 27,0 \\
& $\begin{array}{l}\text { Mam wiedzę, ale chciał(a)bym } \\
\text { się dowiedzieć jeszcze więcej }\end{array}$ & 41 & 41,0 \\
Czy czuje Pan(i), że ma wystarcza- & & \\
jącą wiedzę o swojej chorobie i jej & $\begin{array}{l}\text { Nie mam wiedzy i chcę się cze- } \\
\text { leczeniu? }\end{array}$ & 7 & 7,0 \\
& $\begin{array}{l}\text { goś dowiedzieć } \\
\text { Nie zastanawiam się nad tym, }\end{array}$ & 25 & 25,0 \\
& pomaga mi rodzina & 100 & 100,0 \\
\hline
\end{tabular}

$\chi^{2}=23,36 ; d f=3 ; p<0,001$ 
Analiza wykazała istotny rezultat testu Chi-kwadrat, co oznacza, że zaobserwowane liczebności różnią się istotnie od liczebności oczekiwanych. Okazało się, że większość osób badanych ma wiedzę o swojej chorobie i jej leczeniu, ale chce się dowiedzieć jeszcze więcej (41\%).

Tab. 19. Rezultaty testu U Manna Whitneya dla różnic w poziomie wiedzy na temat profilaktyki przeciwzakrzepowej pomiędzy kobietami a mężczyznami.

\begin{tabular}{lcccccccc}
\hline & \multicolumn{9}{c}{ Płeć } & & & \\
\cline { 2 - 6 } & \multicolumn{1}{c}{ Kobieta $(\mathrm{n}=37)$} & \multicolumn{1}{c}{ Mężczyzna $(\mathrm{n}=63)$} & & & & \\
& $M$ & $S D$ & $M$ & $S D$ & $Z$ & $p$ & $r$ & $\eta 2$ \\
\hline Poziom wiedzy & 9,41 & 2,87 & 8,51 & 2,91 & $-1,69$ & 0,092 & 0,17 & 0,03 \\
\hline
\end{tabular}

$Z$ - wynik testu $U$ Manna Whitneya; $p$ - istotność testu $U$ Manna Whitneya; $r$ rangowy współczynnik korelacji dwuseryjnej Glassa (siła efektu); $\rceil 2$ - eta kwadrat (siła efektu)

Odnotowano brak istotnych różnic w poziomie wiedzy na temat profilaktyki przeciwzakrzepowej pomiędzy kobietami a mężczyznami.

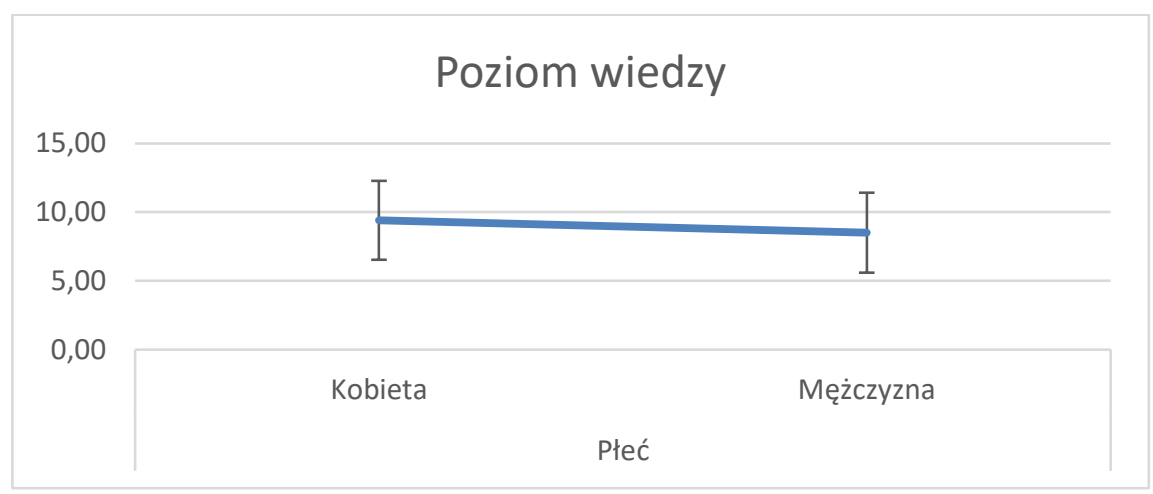

Ryc. 1. Średnie wyniki oceny wiedzy na temat profilaktyki przeciwzakrzepowej pomiędzy kobietami a mężczyznami. 
Tab. 20. Rezultaty testu Kruskala-Wallisa dla różnic w poziomie wiedzy na temat profilaktyki przeciwzakrzepowej pomiędzy pacjentami w różnym przedziale wiekowym.

\begin{tabular}{|c|c|c|c|c|c|c|c|c|c|c|c|c|c|}
\hline & \multicolumn{10}{|c|}{ Wiek } & \multirow[b]{4}{*}{$\chi^{2}$} & \multirow[b]{4}{*}{$p$} & \multirow[b]{4}{*}{$\varepsilon^{2}$} \\
\hline & \multirow{2}{*}{\multicolumn{2}{|c|}{$\begin{array}{c}18-44 \\
\text { lat } \\
(\mathrm{n}=8)\end{array}$}} & \multirow{2}{*}{\multicolumn{2}{|c|}{$\begin{array}{l}\text { 45-54 lat } \\
(\mathrm{n}=8)\end{array}$}} & \multirow{2}{*}{\multicolumn{2}{|c|}{$\begin{array}{c}55-64 \\
\text { lat } \\
(\mathrm{n}= \\
29)\end{array}$}} & \multirow{2}{*}{\multicolumn{2}{|c|}{$\begin{array}{l}\text { 65-74 lat } \\
(\mathrm{n}=41)\end{array}$}} & \multirow{2}{*}{\multicolumn{2}{|c|}{$\begin{array}{c}75 \text { lat i powy- } \\
\dot{z} \text { ej }(\mathrm{n}=14)\end{array}$}} & & & \\
\hline & & & & & & & & & & & & & \\
\hline & $M$ & $\begin{array}{l}S \\
D\end{array}$ & $M$ & $S D$ & $M$ & $\begin{array}{l}S \\
D\end{array}$ & $M$ & $S D$ & $M$ & $S D$ & & & \\
\hline $\begin{array}{l}\text { Poziom } \\
\text { wiedzy }\end{array}$ & $\begin{array}{l}11 \\
25\end{array}$ & $\begin{array}{l}1, \\
16\end{array}$ & $\begin{array}{c}8,8 \\
8\end{array}$ & $\begin{array}{c}3,2 \\
7\end{array}$ & $\begin{array}{l}10, \\
10\end{array}$ & $\begin{array}{l}2, \\
30\end{array}$ & 8,39 & 2,78 & $\begin{array}{c}6,1 \\
4\end{array}$ & 2,71 & $\begin{array}{l}26 \\
50\end{array}$ & $\begin{array}{c}< \\
0,00 \\
1\end{array}$ & $\begin{array}{c}0, \\
27\end{array}$ \\
\hline
\end{tabular}

$M$ - średnia; $S D$ - odchylenie standardowe; $\chi^{2}$ - wynik testu Kruskala-Wallisa; $d f$ liczba stopni swobody; $p$ - istotność testu Kruskala-Wallisa; $\varepsilon^{2}$ - epsilon-kwadrat (siła efektu)

Stwierdzono istotne statystycznie różnice w poziomie wiedzy na temat profilaktyki przeciwzakrzepowej pomiędzy pacjentami w różnym przedziale wiekowym. Siłę tego efektu można uznać za słabą. W celu sprawdzenia, które średnie różnią się między sobą wykonano analizę Dwass-Steel-Critchlow-Fligner pairwise comparisons. Okazało się, że osoby w przedziale wiekowym 18-44 lat mają istotnie wyższy poziom wiedzy na temat profilaktyki przeciwzakrzepowej niż osoby w wieku 65 lat i powyżej. Również stwierdzono, że osoby w przedziale wiekowym 55-64 lat mają istotnie wyższy poziom wiedzy na temat profilaktyki przeciwzakrzepowej niż osoby w wieku 65 lat i powyżej. Ponadto stwierdzono, że osoby w wieku od 65 do 74 lat mają istotnie wyższy poziom wiedzy na temat profilaktyki przeciwzakrzepowej niż osoby w wieku 75 lat i powyżej. 


\section{Poziom wiedzy}

14,00

12,00

10,00

8,00

6,00

4,00

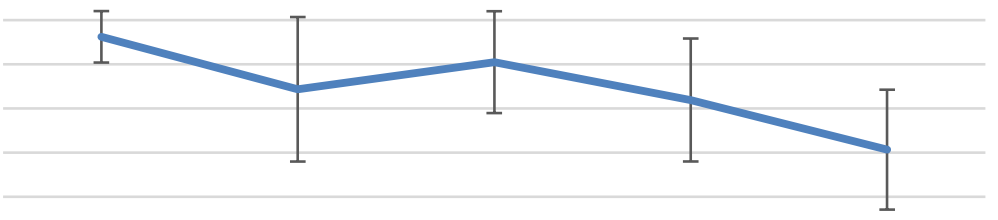

2,00

0,00

18-44 lat 45-54 lat $\quad 55-64$ lat $\quad 65-74$ lat $\begin{gathered}75 \text { lat } i \\ \text { powyżej }\end{gathered}$

Wiek

Ryc. 2. Średnie wyniki oceny wiedzy na temat profilaktyki przeciwzakrzepowej pomiędzy pacjentami w różnym przedziale wiekowym.

Tab. 21. Rezultaty testu Kruskala-Wallisa dla różnic w poziomie wiedzy na temat profilaktyki przeciwzakrzepowej pomiędzy pacjentami o różnym wykształceniu.

\begin{tabular}{lcccccccccccc}
\hline & \multicolumn{1}{c}{ Wykształcenie } & & & \\
\cline { 2 - 8 } & $\begin{array}{c}\text { Podsta- } \\
\text { wowe } \\
(\mathrm{n}=12)\end{array}$ & $\begin{array}{c}\text { Zawodowe (n } \\
=47)\end{array}$ & $\begin{array}{c}\text { Średnie } \\
(\mathrm{n}=23)\end{array}$ & $\begin{array}{c}\text { Wyższe } \\
(\mathrm{n}=18)\end{array}$ & & & \\
& $M$ & $S D$ & $M$ & $S D$ & $M$ & $S D$ & $M$ & $S D$ & $\chi^{2}$ & $p$ & $\varepsilon^{2}$ \\
\hline Poziom & 5,8 & 2,8 & \multirow{2}{*}{7,68} & 2,53 & 10, & 1,0 & 11, & 1,8 & 46,8 & $<$ & 0,4 \\
wiedzy & 3 & 9 & & & 96 & 2 & 17 & 9 & 0 & $\mathbf{0 , 0 0 1}$ & 8 \\
\hline
\end{tabular}

$M$ - średnia; $S D$ - odchylenie standardowe; $\chi^{2}$ - wynik testu Kruskala-Wallisa; $d f$ liczba stopni swobody; $p$ - istotność testu Kruskala-Wallisa; $\varepsilon^{2}$ - epsilon-kwadrat (siła efektu)

Analiza wykazała istotne statystycznie różnice w poziomie wiedzy na temat profilaktyki przeciwzakrzepowej pomiędzy pacjentami o różnym wykształceniu. Siłę tego efektu można uznać za umiarkowanie 
silną. W celu sprawdzenia, które średnie różnią się między sobą wykonano analizę Dwass-Steel-Critchlow-Fligner pairwise comparisons. Okazało się, że osoby z wykształceniem średnim i wyższym mają istotnie wyższy poziom wiedzy na temat profilaktyki przeciwzakrzepowej niż osoby z wykształceniem zawodowym i podstawowym.

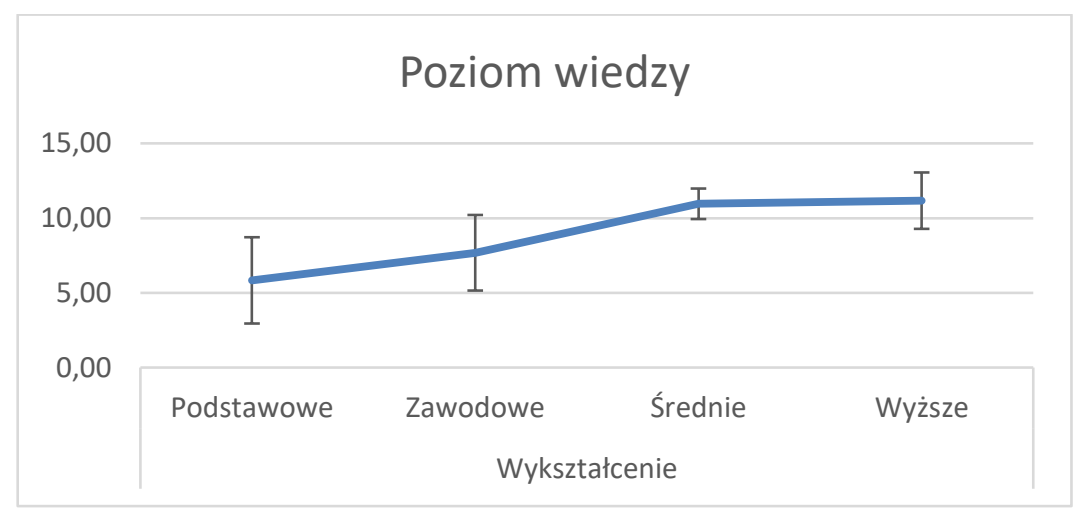

Ryc. 3. Średnie wyniki oceny wiedzy na temat profilaktyki przeciwzakrzepowej pomiędzy pacjentami o różnym wykształceniu. Słupki błędu to plus minus jedno odchylenie standardowe.

Tab. 22. Rezultaty testu Kruskala-Wallisa dla różnic w poziomie wiedzy na temat profilaktyki przeciwzakrzepowej pomiędzy pacjentami o różniej sytuacji materialnej.

\begin{tabular}{|c|c|c|c|c|c|c|c|c|c|}
\hline & \multicolumn{6}{|c|}{ Sytuacja materialna } & \multirow[b]{3}{*}{$\chi^{2}$} & \multirow[b]{3}{*}{$p$} & \multirow[b]{3}{*}{$\varepsilon^{2}$} \\
\hline & \multicolumn{2}{|c|}{$\begin{array}{c}\text { Bardzo dobra } \\
\quad(\mathrm{n}=8)\end{array}$} & \multicolumn{2}{|c|}{$\begin{array}{c}\text { Zadowalająca (n } \\
=80)\end{array}$} & \multicolumn{2}{|c|}{$\begin{array}{c}\text { Przeciętna (n } \\
=12)\end{array}$} & & & \\
\hline & $M$ & $S D$ & $M$ & $S D$ & $M$ & $S D$ & & & \\
\hline $\begin{array}{l}\text { Poziom } \\
\text { wiedzy }\end{array}$ & 10,63 & 2,72 & 9,11 & 2,66 & 5,83 & 2,89 & $\begin{array}{l}14, \\
00\end{array}$ & $\begin{array}{c}< \\
0,00 \\
1\end{array}$ & $\begin{array}{c}0,1 \\
4\end{array}$ \\
\hline
\end{tabular}

$M$ - średnia; $S D$ - odchylenie standardowe; $\chi^{2}$ - wynik testu Kruskala-Wallisa; $d f$ liczba stopni swobody; $p$ - istotność testu Kruskala-Wallisa; $\varepsilon^{2}$ - epsilon-kwadrat (siła efektu) 
Odnotowano istotne statystycznie różnice w poziomie wiedzy na temat profilaktyki przeciwzakrzepowej pomiędzy pacjentami o różnej sytuacji materialnej. Siłę tego efektu można uznać za słabą. W celu sprawdzenia, które średnie różnią się między sobą wykonano analizę Dwass-Steel-Critchlow-Fligner pairwise comparisons. Okazało się, że osoby z przeciętną sytuacją materialną mają istotnie niższy poziom wiedzy na temat profilaktyki przeciwzakrzepowej niż osoby z bardzo dobrą oraz zadowalającą sytuacją materialną.

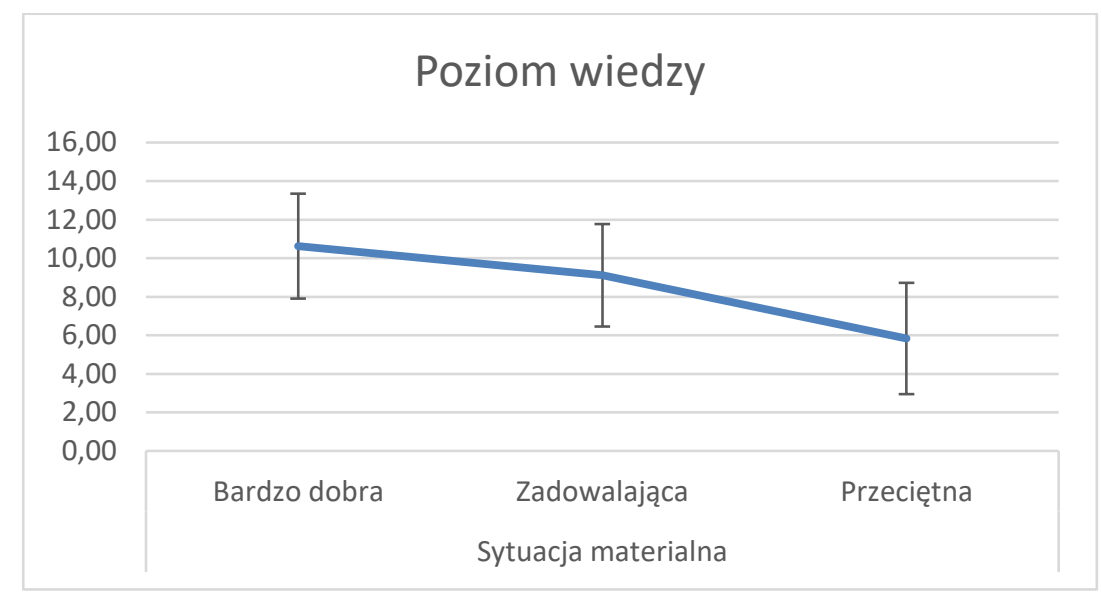

Ryc. 4. Średnie wyniki oceny wiedzy na temat profilaktyki przeciwzakrzepowej pomiędzy pacjentami o różniej sytuacji materialnej.

\section{Dyskusja}

Jedną z najbardziej problematycznych, zarówno pod względem epidemiologicznym, jak i terapeutycznym, jednostek chorobowych z grupy chorób układu sercowo-naczyniowego, jest migotanie przedsionków. Mimo ciągłego postępu w diagnostyce i leczeniu chorób układu krążenia, częstość występowania migotania przedsionków i powikłań zatorowo-zakrzepowych nieustannie wzrasta. Prewencja 
powikłań zakrzepowo-zatorowych u chorych z AF jest więc priorytetowym działaniem w tej grupie pacjentów.

Badaną grupę stanowili pacjenci z migotaniem przedsionków, stosujący leki przeciwzakrzepowe, którzy zostali przyjęci do szpitala z różnych przyczyn, a samo AF nie było główną przyczyną hospitalizacji. Wśród 51\% badanych stwierdzono utrwalone migotanie przedsionków, a u 17\% napadowe (i u tych właśnie chorych była to główna przyczyna hospitalizacji i byli to przeważnie mężczyźni w grupie wiekowej 18-44 lat). Aż 26\% ankietowanych nie potrafiło określić u siebie typu migotania przedsionków.

Identyfikacja ryzyka zakrzepowo-zatorowego w prewencji udarów mózgu i innych powikłań tego typu u pacjentów z AF odgrywa bardzo dużą rolę. Zastosowanie dostępnych obecnie skal oceny takiego ryzyka pozwala na łatwiejsze podjęcie decyzji o rodzaju włączanego leczenia antykoagulacyjnego u chorych z migotaniem przedsionków. Najprostszym narzędziem oceny jest skala CHA2DS2VASc [3].

Wyniki badania wykazały, że ryzyko udaru w ciągu roku, w grupie przebadanych 100 osób, wynosi średnio 11\%. U 32 osób roczne ryzyko udaru wynosi 6,7\%, u 23 osób - 4\%, u 18 osób - 3,2\%, a u 11 osób aż 9,8\%. Tylko 7 osób wśród tych 100 ankietowanych otrzymało 0 punktów, czyli ryzyko nie występuje.

Analizując czynniki ryzyka udaru wśród badanych pacjentów, dane są następujące: z powodu zastoinowej niewydolności serca leczy się aż 92\% badanych, nadciśnienie tętnicze rozpoznano u 87\% (z czego $6 \%$ nie leczy nadciśnienia), na cukrzycę choruje $42 \%$ chorych. Udar mózgu przebyły 22 osoby ( $22 \%$ badanych), a zawał serca 71 osób (71\%). W grupie wiekowej 65-74 lata znajdowało się 41 osób, a w grupie powyżej 75 lat - 14 osób, z czego 17 osób to kobiety. Badana grupa chorych stwierdziła jednoznacznie, że migotanie może prowadzić do groźnych dla życia powikłań. 
W badaniu The Swedish Cohort Artial Fibrilation Study przeprowadzonym w grupie 90490 chorych z AF, których nie poddano leczeniu antykoagulacyjnemu, wykazano bardzo duże ryzyko wystąpienia udaru lub przemijającego napadu niedokrwienia mózgu (TIA) u tych chorych. Brak odpowiedniego leczenia wiąże się dodatkowo z 30-procentową śmiertelnością w ciągu 30 dni od wystąpienia epizodu [4]. Jaxa-Chamiec T. i Budaj A. [5] zajęli się w swojej pracy przestrzeganiem wytycznych, w których to zaleca się stosowanie leczenia przeciwzakrzepowego, w ramach profilaktyki udarów mózgu u pacjentów z migotaniem przedsionków. Do badania włączyli 572 chorych z AF, których podzielili na grupy ryzyka wystąpienia udarów, i którzy przyjmowali warfarynę lub kwas acetylosalicylowy w ciągu ostatnich 6 miesięcy. Ich wyniki pokazały, że 73\% chorych z grupy wysokiego ryzyka wystąpienia udaru mózgu, przyjmuje leczenie przeciwzakrzepowe po incydencie migotania przedsionków, 59\% z nich stosowało warfarynę, 28\% kwas acetylosalicylowy, a $24 \%$ badanych nie przyjmowało żadnego leku antykoagulacyjnego.

W terapii antykoagulantami duże znaczenie ma nie tylko dobór właściwego leku, ale także samo podejście chorego do leczenia. Regularne przyjmowanie leków oraz zrozumienie istoty leczenia, pozwalają na skuteczne zapobieganie incydentom zakrzepowo-zatorowym.

W badaniach własnych wykazano, że większość pacjentów (79\%) stosuje leki przeciwzakrzepowe nowej generacji (takie jak: Xarelto, Pradaxa, i Eliquis), 21\% leczy się za pomocą antagonistów witaminy $\mathrm{K}$ (czyli Acenocumarol i Warfin). Większą popularnością w grupie „starych" leków przeciwzakrzepowych cieszył się Warfin (17\%). Jesli chodzi o leki z grupy NOAC, to wyniki przedstawiają się na mniej więcej jednakowym poziomie: Xarelto - 37\%, Eliquis - 25\% i Pradaxa - $17 \%$.

Na pytanie, czy respondenci zmieniliby stosowany lek na antykoagulant nowej generacji, aż 78\% odpowiedziało, że już stosuje taki lek, a tylko 2\% zadeklarowało chęć zmiany, ze względu na brak 
konieczności kontroli wskaźnika INR. 13\% ankietowanych uznało, że leki nowej generacji są zbyt drogie (i były to głównie osoby z przeciętną sytuacją materialną), a pozostałe $7 \%$ nie chce zmiany leku, gdyż już przyzwyczaili się do dotychczas stosowanego preparatu.

Większość ankietowanych, zapytana od jak dawna stosuje lek „rozrzedzający krew”, odpowiedziała, że od kilku lat (66\%). Tylko 4\% stosuje te leki od kilku tygodni, a 30\% od kilku miesięcy. Lekarzem, włączającym lek antykoagulacyjny, wg 86\% badanych, był kardiolog, a $14 \%$ wskazało, że lekarz innej specjalności. W związku z powyższym obserwujemy podobny wynik procentowy w pytaniu o to, kto wytłumaczył pacjentowi działanie tego leku. W tym przypadku jest to lekarz przepisujący lek (81\%). Duży udział w tym zakresie (17\%) miały pielęgniarki, wskazane przez ankietowanych, jako osoby przyczyniające się do poszerzenia ich wiedzy, na temat działania stosowanego leku.

Lomper K. i współautorzy [6] oceniali stan wiedzy na temat terapii przeciwzakrzepowej u pacjentów leczonych Acenocumarolem. Do badania włączyli grupę 61 osób (średnia wieku 70). Ich badania wykazały, że poziom wiedzy chorych był niski. Poziom wykształcenia i płeć respondentów oraz przyczyna hospitalizacji, nie miały związku z wiedzą tych osób. Udowodniono natomiast negatywną zależność pomiędzy wiekiem badanych, a poziomem ich wiedzy. Osoby młodsze cechowały się lepszym poziomem wiedzy, niż osoby starsze. Również Kubica A. i współautorzy [7] badali poziom wiedzy oraz satysfakcji z leczenia u pacjentów z migotaniem przedsionków, stosujących Warfarynę. Przebadali oni 183 respondentów, wśród których 40\% wykazało deficyt wiedzy na temat leczenia Warfaryną oraz jej interakcji z innymi lekami. Wyższy poziom zadowolenia z leczenia dodatnio korelował z poziomem wiedzy pacjentów ( $\mathrm{p}=0,001)$. Jako przyczyny nieprzyjmowania Warfinu, pacjenci ci wskazywali: obawy związane z interakcją z innymi lekami (36\%), pominięcie dawki przez zapomnienie (26\%) oraz obawy 
przed działaniami niepożądanymi (25\%). Lepszy poziom wiedzy i satysfakcji z leczenia wiązały się z utrzymywaniem zakresu INR w normie.

Kolejna kwestia dotyczyła kontroli wskaźnika INR podczas terapii antykoagulantami i jego prawidłowych wartościach. Jeśli chodzi o powyższe badanie, to respondenci wykazali się dużą wiedzą na temat tego, jak często należy kontrolować wskaźnik INR, podczas przyjmowania Warfinu i Sintromu. 61\% ankietowanych odpowiadało prawidłowo, że raz w miesiącu. Również prawidłowej odpowiedzi udzielali respondenci na pytanie o wartość terapeutyczną INR. 74\% odpowiedziało poprawnie, że jest to przedział między 2 a 3 . W większości przypadków (79\%) pacjenci przyjmowali leki niewymagające ustalania dawki INR, a w przypadku stosowania przez chorych Warfinu lub Sintromu, dawkę leku ustalał lekarz rodzinny, na podstawie wyniku INR, kontrolowanego raz w miesiącu.

Podobne wyniki uzyskał w swojej pracy badawczej Kardas P. [8], który badał wpływ różnych czynników na przestrzeganie leczenia przeciwzakrzepowego przez pacjentów z migotaniem przedsionków, leczonych na oddziałach chorób wewnętrznych. Do swojego badania włączył on 247 pacjentów z rozpoznanym już wcześniej AF. Wykazał, że u więcej niż $50 \%$ chorych z AF, profilaktyka przeciwzakrzepowa jest stosowana prawidłowo. 54\% pacjentów oznaczało wskaźnik INR raz w miesiącu, a wartości prawidłowe wskaźnika odnotowano u $56 \%$ chorych.

Kolejna analiza wykazała znajomość zasad stosowanych podczas przyjmowania przez pacjentów leków antykoagulacyjnych. Respondenci, zapytani o to, czy leki przeciwkrzepliwe mogą być niebezpieczne dla osoby je przyjmującej, odpowiedzieli prawie jednogłośnie (84\%), że tak, gdyż zbyt duża dawka może wywołać krwawienie. Błędnej odpowiedzi udzieliło $3 \%$ ankietowanych, a $13 \%$ nie umiało odpowiedzieć na to pytanie. 
W kwestii przestrzegania pory i dawkowania leku przeciwkrzepliwego, badani pacjenci stosowali się do zaleceń (80\%), tylko 9\% przyjmowało lek o różnych porach dnia, a $11 \%$ zdarzyło się całkowicie pominąć dawkę. Aż 82\% deklarowało, że w przypadku pominięcia zleconej dawki leku, weźmie ją w jak najkrótszym czasie od wyznaczonego. Pacjenci przyjmujący leki przeciwkrzepliwe wiedzieli również, że przed planowanymi zabiegami chirurgicznymi, okulistycznymi, czy stomatologicznymi, muszą poinformować lekarza o stosowaniu takich leków (64\%). Podobny wynik (65\%) uzyskano w pytaniu o iniekcje domięśniowe w trakcie terapii antykoagulantami. Pacjenci wiedzieli, że w miarę możliwości należy unikać przyjmowania zastrzyków domięśniowych, a w razie ich konieczności powinno się zastosować kilkuminutowy ucisk.

Gorczyca-Siudak i Siudak [9] objęli badaniem 55 losowo wybranych chorych, hospitalizowanych w oddziale kardiologii Wojewódzkiego Szpitala Specjalistycznego w Lublinie w 2014 roku. Średni wiek pacjentów wynosił 67 lat. Długość leczenia antykoagulacyjnego w badanej grupie była zróżnicowana - od 2 tygodni do 27 lat i najczęściej wprowadzana podczas pobytu w szpitalu. Większość chorych (82\%) wiedziała, że antykoagulanty mają chronić przed udarem mózgu, ale też zbyt duża dawka może wywołać krwawienie (60\%). Ankietowani deklarowali, że ściśle przestrzegają dawkowania i pory przyjmowania leku w ciągu dnia (78\%). Co czwarty pacjent odpowiadał, że rzadko, ale zdarza mu się zapomnieć o przyjęciu leku, a dwie osoby przyznały, że kilka razy w miesiącu zapomniały o przyjęciu zaleconej dawki. W razie pominięcia dawki w danym dniu o ustalonej porze chorzy najczęściej twierdzili poprawnie, że wezmą zapomnianą dawkę leku w jak najkrótszym czasie od wyznaczonej stałej godziny przyjmowania, w następnych dniach kontynuując stosowanie wg wcześniej ustalonego schematu (62\%). 79\% ankietowanych miała świadomość, że zastrzyki domięśniowe w ich przypadku mogą być niebezpieczne, a 90\% wiedziało, 
że trzeba poinformować lekarza o terapii przeciwzakrzepowej przed planowanym zabiegiem chirurgicznym.

Kolejna analiza dotyczyła czynników nasilających działanie doustnych leków przeciwzakrzepowych oraz objawów ich przedawkowania. Na pytanie, czy przyjmowanie leków przeciwbólowych i przeciwzapalnych, takich jak: Paracetamol, Ketonal, Pyralgina itp., w trakcie stosowanej terapii przeciwkrzepliwej jest bezpieczne, 65\% respondentów odpowiedziało prawidłowo, że nie jest, ponieważ leki te nasilają działanie antykoagulantów i mogą powodować krwawienia. 18\% badanych nie potrafiło udzielić odpowiedzi na to pytanie. Jeśli chodzi o spożywanie zielonych warzyw, takich jak: brokuły, sałata, kapusta, czy szpinak, podczas stosowania leków przeciwkrzepliwych, to aż $84 \%$ badanych wiedziało, że osłabiają one działanie tych leków, a co za tym idzie zmniejszają INR. Pozostałe 16\% udzieliło błędnej odpowiedzi. Podobnie, jak w poprzednim pytaniu, respondenci wiedzieli, że przeciwwskazany jest również alkohol, gdyż nasila on działanie leków „rozrzedzających krew" i może powodować krwawienia (82\%). W przypadku pojawienia się u chorych siniaków, krwawień z nosa i dziąseł lub czarnych stolców, większość z nich (83\%) wiedziała, że są to pierwsze objawy przedawkowania leku przeciwkrzepliwego i należy zgłosić się do lekarza.

Korzonek i Zembik [10] wykazały, że stan wiedzy pacjentów na temat leczenia przeciwzakrzepowego, powikłań, skutków ubocznych i interakcji, jest niedostateczny. Wśród 180 badanych osób najliczniejszą grupę (63 osoby) stanowili pacjenci w przedziale wiekowym 50-70 lat. U 110 chorych stosowany był kwas acetylosalicylowy, u 40 klopidogrel, a u 30 Acenocumarol. Najczęstszą przyczyną stosowania tych leków była choroba wieńcowa i zawał serca (103 osoby), a następnie migotanie przedsionków (77 osób). W badanej grupie jedynie $51 \%$ badanych twierdziło, że zostali poinformowani o działaniach ubocznych tych leków, a $22 \%$ chorych nie otrzymało żadnej informacji. Większość badanych $(60 \%)$ przyznała, że informacje o lekach pochodzą od 
lekarza, 23\% z ulotki dołączonej do leku, $15 \%$ od pielęgniarki, a $2 \%$ z Internetu. Swoją wiedzę na temat działania leków jako dobrą oceniło $23 \%$, jako średnią $57 \%$, a brak wiedzy deklarowało $20 \%$. W podobnym badaniu wśród 180 pacjentów Szpitala Specjalistycznego w Pile w 2016 roku, Sawicka-Powierza i wsp. [11] udowodnili, że zakres edukacji i wiedzy pacjentów na temat leczenia przeciwzakrzepowego jest niewystarczający. Pacjenci, zapytani o wpływ niektórych produktów spożywczych i warzyw na działanie leków przeciwzakrzepowych, odpowiadali, że pokarm nie ma wpływu na działanie tych leków (78\%). Wpływ równocześnie przyjmowanych innych leków na działanie antykoagulantów uznało 46\%, negowało 54\%. Sporadyczne spożywanie alkoholu w trakcie leczenia potwierdziło $23 \%$ badanych. Objawy przedawkowania leku przeciwkrzepliwego potrafiło wymienić $45 \%$ respondentów.

Wiedza pacjentów na temat profilaktyki przeciwzakrzepowej w migotaniu przedsionków jest na dobrym poziomie. Na pytanie, czy migotanie przedsionków może prowadzić do groźnych dla życia powikłań, respondenci w $65 \%$ odpowiedzieli, że tak. $27 \%$ ankietowanych stwierdziło, że ma wystarczającą wiedzę o swojej chorobie i jej leczeniu, 41\% ma wiedzę, ale chętnie dowiedziałoby się więcej, 7\% nie ma wiedzy, ale chciałoby ja poszerzyć, a $25 \%$ nie zastanawia się nad tym, gdyż pomaga im rodzina.

Broda i wsp. [12] dokonali przeglądu literatury przedmiotu z 2010 roku, dotyczącej czynników wpływających na skuteczność terapii u pacjentów z AF leczonych doustnymi antykoagulantami. Wśród czynników wpływających na zastosowanie się chorego do zaleconego leczenia wymienili: wiedzę pacjenta, jego przekonania i umiejętności, powiązania z systemem opieki zdrowotnej, czynniki ekonomiczne, relacje pacjent-lekarz oraz cechy demograficzne, psychospołeczne i osobowościowe chorego. U 78,9\% uczestników wykazano wysoki poziom 
motywacji do stosowania przepisanej terapii, a u 100\% badanych stwierdzono wysoki poziom wiedzy na temat stosowanego leczenia.

Badania wykazały brak istotnych różnic w poziomie wiedzy na temat profilaktyki przeciwzakrzepowej pomiędzy kobietami a mężczyznami. Stwierdzono za to istotne różnice w poziomie wiedzy pomiędzy pacjentami w różnym przedziale wiekowym. Okazało się, że osoby w przedziale wiekowym 18-44 lat mają istotnie wyższy poziom wiedzy na temat profilaktyki przeciwzakrzepowej, niż osoby w wieku 65 lat i powyżej. Badania wykazały również różnice w poziomie wiedzy na temat profilaktyki przeciwzakrzepowej pomiędzy pacjentami o różnym wykształceniu. Okazało się, że osoby z wykształceniem średnim i wyższym mają istotnie wyższy poziom wiedzy na temat profilaktyki przeciwzakrzepowej niż osoby z wykształceniem zawodowym i podstawowym. Odnotowano też różnice w poziomie wiedzy pomiędzy pacjentami o różnej sytuacji materialnej. Osoby z przeciętną sytuacją materialną mają istotnie niższy poziom wiedzy na temat profilaktyki przeciwzakrzepowej, niż osoby z bardzo dobrą oraz zadowalającą sytuacją materialną.

Specyfika przewlekłej doustnej profilaktyki przeciwzakrzepowej wymaga stałej współpracy pomiędzy pracownikami służby zdrowia, a dobrze wyedukowanym pacjentem. Odpowiednio przekazana wiedza jest sposobem poprawy skuteczności i bezpieczeństwa strategii leczenia przeciwzakrzepowego. Warunkiem właściwej motywacji do leczenia, jest wyjaśnienie pacjentowi przede wszystkim celów terapii. Skuteczność i efektywność profilaktyki wymaga odpowiedniej wiedzy na temat jej zasad, a bezpieczeństwo zależy od świadomości możliwych działań niepożądanych i znajomości ich objawów. Wobec narastającej liczby chorób układu sercowo-naczyniowego oraz starzejącej się populacji pacjentów przyjmujących leki przeciwzakrzepowe, głównie ze wskazań kardiologicznych, jedynie wszechstronna edukacja tych chorych 
pozwoli na świadome wyeliminowanie zagrożeń, jakie niesie za sobą tego typu terapia.

\section{Wnioski}

1. Poziom wiedzy pacjentów, na temat profilaktyki przeciwzakrzepowej w migotaniu przedsionków, jest na dobrym poziomie i odpowiada aktualnej wiedzy medycznej.

2. Pacjenci z rozpoznanym migotaniem przedsionków znają zasady postępowania podczas stosowania doustnych leków przeciwzakrzepowych.

3. Analiza wykazała, że pacjenci potrafią wskazać czynniki ryzyka predysponujące do powstania powikłań zakrzepowo-zatorowych, w tym udaru mózgu.

4. Badanie wykazało, że u pacjentów przyjmujących doustne leki przeciwzakrzepowe nie występuje deficyt wiedzy z zakresu kontroli wskaźnika INR i jego wartości terapeutycznej.

5. Pacjenci posiadają wiedzę na temat czynników nasilających działanie doustnych leków przeciwzakrzepowych oraz objawów ich przedawkowania.

\section{Zalecenia dla praktyki pielęgniarskiej}

Pielęgniarki sprawujące opiekę nad z migotaniem przedsionków powinny systematycznie doskonalić zasób swojej wiedzy i umiejętności z zakresu profilaktyki przeciwzakrzepowej w migotaniu przedsionków, zasad terapii antykoagulantami, ich działania, objawów ubocznych, przeciwwskazań i interakcji, czynników ryzyka udaru mózgu. 


\section{Bibliografia/Bibliography:}

1. Zapolski T., Wysokiński A. Znaczenie migotania przedsionków w powstawaniu zatorowości systemowej. Pol. Prz. Kardiol. 2010; 12(1):45-54.

2. Duda B., Szumowski Ł., Walczak F. Leczenie przeciwzakrzepowe w migotaniu przedsionków a czynniki zagrożenia udarem. Forum Medycyny Rodzinnej. 2011;5(3):222-228.

3. Życińska K., Borowiec A. Wytyczne ESC dotyczące leczenia migotania przedsionków w 2016 roku, opracowane we współpracy z EACTS. Kardiologia Polska. 2016;74(12):1359-1443.

4. Wożakowska-Kapłon B., Gorczyca-Michta I., Filipiak K., Siebert J. Prewencja powikłań zakrzepowo-zatorowych u chorych z migotaniem przedsionków - propozycja algorytmu dla lekarzy rodzinnych. Forum Med. Rodz. 2013;7(1):1-15.

5. Jaxa-Chamiec T., Budaj A. Nowe kierunki badań nad profilaktyką powikłań zatorowych u chorych z migotaniem przedsionków. Udział kliniki Kardiologii CMKP w wieloośrodkowych badaniach klinicznych. Post. Nauk Med. 2010;23(12):905-909.

6. Lomper K., Rycombel A., Uchmanowicz I. Przestrzeganie i zastosowanie się do leczenia antykoagulacyjnego oraz antyarytmicznego pacjentów z migotaniem przedsionków. Chor. Serca Naczyń 2014;11(4): 230-237.

7. Kubica A., Ratajska A., Sinkiewicz W. Przyczyny złej współpracy lekarz pacjent w terapii przewlekłej. Folia Card. Exc. 2010;5:78-83.

8. Kardas P. Polskiego pacjenta portret własny. Raport o przestrzeganiu zaleceń terapeutycznych przez polskich pacjentów. Fundacja na rzecz Wspierania Rozwoju Polskiej Farmacji i Medycyny. Starogard Gdański 2010:2-40. 
9. Gorczyca-Siudak D., Siudak Ł., Mosiewicz J. Poziom wiedzy na temat profilaktyki przeciwzakrzepowej antagonistami witaminy K wśród pacjentów z migotaniem przedsionków. Medycyna Ogólna i Nauki o Zdrowiu. 2016;22(1):33-39.

10. Korzonek M., Zembik M. Wiedza chorych na temat zagrożeń wynikających z przyjmowania leków przeciwzakrzepowych i antyagregacyjnych ze wskazań kardiologicznych. Pom J Life Sci 2015;61 (4):448-453.

11. Sawicka-Powierza J., Rogowska-Szadkowska D., Ołtarzewska A.M., Chlabicz S. Czynniki wpływające na działanie doustnych antykoagulantów. Interakcje z lekami i pożywieniem. Pol Merkuriusz Lek. 2016;24(143):458-462.

12. Broda G., Kurjata P., Piwońska A.: Wieloośrodkowe Badanie Stanu Zdrowia Ludności. Instytut Kardiologii im. Prymasa Tysiąclecia Stefana Kardynała Wyszyńskiego. Warszawa 2010:1-5. 